\title{
Iwona Boguszyńska
}

Uniwersytet Wrocławski

\section{Restrukturyzacja przedsiębiorstw Europy Środkowo-Wschodniej i Azji Centralnej w dobie transformacji}

\section{Transformacja a sektor przedsiębiorstw}

Przechodzenie od gospodarki centralnie planowanej do wolnorynkowej jest sytuacją, która oznacza zupełnie nowe zasady i warunki funkcjonowania podmiotów gospodarczych. Jedną z podstawowych cech gospodarki nakazowo-rozdzielczej było dominujące znaczenie sektora państwowego zarówno w skali produkcji, jak i zatrudnienia. Sektor prywatny był surowo ograniczany, a jego znaczenie było marginalne - jego rola sprowadzała się bowiem do łagodzenia napięć na rynku (Kamińska 2006). Przeważały przedsiębiorstwa duże oraz średnie, zwłaszcza w strukturze przemysłowej (pozostałe gałęzie gospodarki, takie jak handel i usługi, nie były rozwijane). Przedsiębiorstwa te funkcjonowały w warunkach odgórnie ustalanych cen towarów oraz wielkości produkcji, wobec czego nie obowiązywała ich zasada dostosowywania produkcji do popytu i związane z tym zyski (brak zasady rachunku ekonomicznego). Środki z budżetu były redystrybuowane przez państwo między przedsiębiorstwa a gospodarstwa domowe na zasadzie subwencji oraz programów świadczeń (Balcerowicz, Gelb 1995).

Rozpoczęcie transformacji systemowej diametralnie zmieniło tę sytuację. Przedsiębiorstwa, jako podmioty gospodarcze, musiały dostosować się do warunków wolnorynkowych, gdzie ilością, jakością oraz strukturą produkcji, a także cenami towarów rządzi popyt i od niego zależą zyski firmy, a co za tym idzie, jej przetrwanie na rynku. Warto jednak zwrócić uwagę na fakt, że przedsiębiorstwa można również potraktować jako swego rodzaju organizację, która stanowi element transformacji gospodarczej. Są one bowiem czynnikiem stabilizacji makroekonomicznej gospodarki w warunkach przejścia systemowego (Bąk 2006).

W odpowiedzi na wymogi wolnego rynku, by przetrwać, przedsiębiorstwa musiały stać się konkurencyjne i rentowne. Podstawowym działaniem w transformacji przedsiębiorstw jest zmiana struktury własności, czyli przywrócenie sektorowi prywatnemu większości udziału w gospodarce narodowej. Dokonuje się to dwoma sposobami - na drodze powstawania nowych prywatnych przedsiębiorstw oraz na drodze prywatyzacji firm państwowych. Jest to o tyle istotne, że prywatyzacja potencjału wytwórczego (zwłaszcza w przemyśle) jest jednym z podstawowych warunków poprawnego funkcjonowania gospodarki rynkowej (Misztal 2000).

Kolejnym elementem transformacji jest zmiana struktury przedsiębiorstwa, czyli restrukturyzacja. Dotyczy ona między innymi takich aspektów funkcjonowania firmy, jak: zmiana systemu zarządzania, wzrost wydajności pracy, wzrost produktywności, majątku trwałego czy efektywności inwestycji. Działania te oczywiście występują nie tylko w czasie przejścia systemowego, ale również w zdrowo działającej gospodarce wolnorynkowej. Dzieje się tak, ponieważ każdy system gospodarczy jest dynamiczny i ulega zmianom (rozwojowi), za którymi 
podążają przedsiębiorcy. Jednak różnica polega na tym, że w takim wypadku jest to restrukturyzacja zamierzona, nakierowana na maksymalizację zysków, poprawę efektywności, optymalne wykorzystanie zasobów i zwiększenie konkurencyjności firmy. Tak rozumiana restrukturyzacja przedsiębiorstwa często nie jest nawet wynikiem chęci podążania za trendami ekonomicznymi, ale wręcz ich wyprzedzania, narzucania innym podmiotom gospodarczym konkurencji własnych innowacji w zakresie produkcji, zarządzania czy marketingu. Natomiast w wypadku przedsiębiorstw w dobie transformacji, restrukturyzacja jest procesem wymuszonym i całkowicie niezbędnym dla dalszego funkcjonowania danych podmiotów gospodarczych.

Zasadniczo zatem do podstawowych celów w zakresie szeroko pojętej restrukturyzacji przedsiębiorstw w dobie przemian ustrojowych można zaliczyć:

- dostosowanie się do zmian w otoczeniu, umiejętność przetrwania w warunkach nowych zasad gry gospodarczej,

- zwiększenie konkurencyjności (m.in. przez zmiany w strukturze i sposobie produkcji) i utrzymanie jej na rynku.

Restrukturyzacja odbywa się na kilku podstawowych płaszczyznach, oprócz restrukturyzacji własnościowej wyróżnić można restrukturyzację produktową, eksportową, majątkową czy zatrudnienia.

W początkowych latach transformacji ustrojowej w Polsce sytuacja dużych przedsiębiorstw, zarówno prywatnych, jak i państwowych, była zbliżona - w mniejszym lub większym stopniu i na różną skalę próbowały one wprowadzać działania restrukturyzacyjne. Były to jednak najczęściej (zwłaszcza w wypadku przedsiębiorstw niesprywatyzowanych) doraźne działania, wystarczające, co prawda do chwilowego wyjścia z recesji (transformacyjnej), ale nie do przeżycia i, co najważniejsze, rozwijania się w warunkach gospodarki wolnorynkowej. W zasadzie przedsiębiorstwa nie miały żadnych długofalowych strategii rozwoju firmy, która pozwoliłaby na trwałe umocnienie pozycji rynkowej. Od tego, czy przedsiębiorstwa taką strategię nauczą się budować, zależało ich przetrwanie na wolnym rynku.

Na początku lat 90 . XX wieku, wraz z rozpoczęciem transformacji systemu gospodarczego, pojawił się problem poważnego załamania produkcji przemysłowej. Wpływ na to zjawisko miały m.in.: spadek siły nabywczej społeczeństwa, konkurencja wyrobów pochodzących z importu oraz utrata dotychczasowych rynków zbytu, funkcjonujących w ramach Rady Wzajemnej Pomocy Gospodarczej (Bazydło, Smętkowski, Wieloński 2001).

Jeszcze w 1999 roku prawie 70\% przedsiębiorstw notowało ujemną rentowność sprzedaży. Świadczyło to o ,płytkiej” restrukturyzacji, wdrażanej na zbyt małą skalę, nieefektywnej. Jednak należy przypuszczać, że gdyby nie wprowadzano jej choćby i w tym ograniczonym zakresie, to sytuacja polskich przedsiębiorstw byłaby w tym czasie jeszcze gorsza (Krajewski 2004).

Szybciej zaczęły się przystosowywać przedsiębiorstwa sprywatyzowane, zwłaszcza te w rękach lub z udziałem kapitału zagranicznego, gdyż zachodni inwestorzy, wraz z przejęciem kontroli w firmie, wnosili znane ze swoich rynków sposoby zarządzania zasobami, procesami produkcji, organizacji pracy, a także wdrażali nowe (dla polskich przedsiębiorstw) technologie. Zaczęło powoli pojawiać się zagrożenie, że całe branże gospodarki, w których dominował sektor państwowy i którymi zainteresowanie prywatnych inwestorów było znikome, będą skazane na likwidację. Widoczna asymetria restrukturyzacji dotyczyła zresztą nie tylko płaszczyzny branżowej, ale także np. struktury własności kapitału. Sytuacja ta wyłoniła z jednej strony silne jednostki, które można określić mianem liderów, a z drugiej strony jednostki słabe, nieradzące sobie w nowych warunkach gospodarczych (nastąpiła więc swoista polaryzacja). 
W takiej sytuacji powstał dylemat: czy pozwolić, zgodnie z regułami wolnego rynku, na upadek nierentownych przedsiębiorstw, czy też, całkowicie zaprzeczając zasadom wolnorynkowym, subsydiować te przedsiębiorstwa z budżetu państwa. Za pierwszym rozwiązaniem przemawiało kierowanie się nadrzędnym celem wszystkich reform, czyli dojściem do gospodarki kapitalistycznej, natomiast drugie rozwiązanie zjednywało sobie zwolenników obawiających się bezrobocia lub upadku całych wręcz branż przemysłowych (np. włókienniczej). Próbowano znaleźć rozwiązania pośrednie, stąd też wraz z dopuszczeniem do funkcjonowania państwowych nierentownych przedsiębiorstw, jednocześnie promowano aktywną politykę przemysłową, mającą pobudzić eksport, zachęcić przedsiębiorców do inwestycji i rozwoju technologicznego firmy. Miało to na celu wspomóc rozwój firmy, a nie jedynie przedłużenie jej agonii. Jednak w rzeczywistości w wielu przypadkach subsydiowanie tych przedsiębiorstw było właśnie sztucznym podtrzymywaniem ich działalności aż do momentu i tak nieuniknionego upadku.

\section{Przebieg procesów restrukturyzacji na różnych płaszczyznach działalności przedsiębiorstw} Restrukturyzacja produktowa jest to zmiana lub dostosowanie profilu działalności firmy do potrzeb popytowych rynku. W dobie transformacji przedsiębiorstwa musiały nauczyć się odpowiadać na popyt zgłaszany przez konsumentów na rynku, by efektywnie na nim funkcjonować. Było to o tyle trudne, że popyt, zarówno wewnętrzny, jak i zewnętrzny, w pierwszym okresie po upadku komunizmu gwałtownie spadł (rozpad rynku RWPG, trudny dostęp do rynków zachodnich). Ponadto przedsiębiorstwa krajowe stanęły przed wyzwaniem konkurencji zagranicznej, która przedtem nieznana, teraz przejawiała się w niekontrolowanym imporcie, tzw. dzikim imporcie (Koźmiński 1998). Problemem dla dobrze prosperujących i gruntownie zrestrukturyzowanych przedsiębiorstw była również nieuczciwa konkurencja, czyli na przykład przedsiębiorstwa funkcjonujące w szarej strefie, stosujące oszustwa podatkowe czy sztucznie przedłużające swoje funkcjonowanie w stanie upadłości i likwidacji. Wszystko to sprawiało, że przedsiębiorstwa, które chciały przetrwać na rynku i dalej się rozwijać, musiały nauczyć się dostosowywać swoją strukturę i jakość produkcji do popytu, by pozostać konkurencyjnymi na rynku.

Oczywiście w warunkach niskiego popytu wewnętrznego pojawiła się kwestia walczenia o rynki zewnętrzne i próba znalezienia konsumenta za granicą. Ekspansja eksportowa jest ważnym sprawdzianem skuteczności przeprowadzonej restrukturyzacji. Widoczna jest różnica między podejściem do rozwoju eksportu między przedsiębiorstwami prywatnymi a państwowymi - otóż te pierwsze stawiają na wprowadzenie nowych produktów, często nowoczesnych, o wysokim stopniu przetworzenia, stąd potrzebny jest też rozwój efektywnego marketingu, ułatwiającego dotarcie do konsumenta. Natomiast w państwowych firmach raczej modernizuje się wytwarzane dotychczas produkty, co jednak nie zawsze podnosi ich jakość i nie wpływa na obniżenie kosztów produkcji.

Inny problem, przed którym stanęli przedsiębiorcy w dobie reform gospodarczych, to zmiana źródeł finansowania inwestycji. Ponieważ dotacje rządowe nie mogły być i nie były już głównym ich źródłem, najczęściej były to środki własne. Stało się to o tyle niekorzystne, że jeśli przedsiębiorstwo miało problemy z rentownością, to jego środki własne również były niewielkie, co ograniczało jego zdolność inwestycyjną, a to z kolei nie pozwalało na zwiększenie rentowności. I tak zamykało się błędne koło. Potrzebne były zatem działania w obszarze polityki gospodarczej, na przykład wprowadzenie preferencji dla inwestorów w postaci ulg podatkowych. 
Często wymienianym czynnikiem ograniczającym aktywność inwestycyjną przedsiębiorstw, oprócz niedostatecznych środków własnych, była niepewna, niestabilna sytuacja polityczna kraju (w okresie przemian ustrojowych), która według właścicieli firm mogła przekładać się na niekorzystną sytuację gospodarczą.

Jednak należy nadmienić, że pomimo tych trudności i pesymistycznych ocen przyszłości gospodarczej kraju, przedsiębiorstwa realizowały restrukturyzację zarówno produktową, jak i majątkową. O ile w 1990 roku liczba firm dysponujących majątkiem porównywalnym z uznanymi światowymi firmami była znikoma, o tyle w 2004 roku ich udział na rynku polskim szacowano na poziomie około 20\% (Krajewski 2004).

Kolejnym wyzwaniem dla przedsiębiorstw po upadku systemu komunistycznego była kwestia nadmiernego zatrudnienia i nieefektywnego wykorzystania siły roboczej. W gospodarce centralnie planowanej nie występowało zjawisko bezrobocia, przynajmniej jawnego, z racji etatyzacji gospodarki, w wyniku której rozrastała się na przykład kosztowna w utrzymaniu oraz nieefektywna biurokracja. Również zatrudnienie przy procesie produkcji było nadmierne i w wyniku spadku popytu i modernizacji procesu produkcji (niezbędnego przecież dla osiągnięcia nowoczesności, niższych kosztów produkcji i konkurencyjności na rynku), trzeba było je coraz bardziej ograniczać. Na początku lat 90. liczne zwolnienia były powodem napięć i niepokojów społecznych. Osiągnięcie optymalnego poziomu zatrudnienia jest jednak niezbędne, aby przedsiębiorstwo mogło przetrwać na wolnym rynku. Poziom ten stosunkowo szybko osiągnęło większość firm sprywatyzowanych (z kapitałem krajowym i zagranicznym), natomiast w przedsiębiorstwach państwowych istotną barierą okazał się opór związków zawodowych (który zresztą w niektórych wypadkach aktywny jest do chwili obecnej), a także brak środków finansowych na odprawy dla pracowników przy zwolnieniach grupowych (Krajewski 2004).

Kwestią powiązaną z zatrudnieniem jest również system wynagrodzeń, który powinien zmierzać do silniejszego powiązania poziomu płac z efektami pracy. Systemy motywacyjne były szybciej i powszechniej wprowadzane w przedsiębiorstwach sprywatyzowanych, natomiast w przedsiębiorstwach państwowych obserwowano wyższe (niż w prywatnych) przeciętne wynagrodzenie. Związane to było nie tyle z lepszą sytuacją ekonomiczną tych podmiotów, ile z naciskami środowisk związkowych oraz niekonsekwencją organów państwowych, które nie zawsze kierowały się regułami wolnorynkowymi wobec przedsiębiorstw państwowych.

Należy także wspomnieć, że system preferencji płacowych dla pracowników wykonawczych (charakterystyczny dla gospodarki nakazowo-rozdzielczej) przestał istnieć; w okresie transformacji preferencje płacowe kierowane były na kadry kierownicze i piony odpowiedzialne za sprzedaż, marketing, finanse, rachunek ekonomiczny, zarządzanie, koszty, zawieranie umów itp. (Krajewski 2004).

\section{Analiza wskaźnika restrukturyzacji przedsiębiorstw Europy Środkowo-Wschodniej i Azji Centralnej}

Wskaźnik restrukturyzacji przedsiębiorstw (ang. index of enterprise reform) został opracowany przez Europejski Bank Odbudowy i Rozwoju (EBRD) jako jeden z zestawu wskaźników tzw. transition indicators, publikowanych w dorocznym raporcie pt. Transition Report. Są to wskaźniki służące do opisu i oceny postępów w transformacji gospodarki od systemu nakazowo-rozdzielczego do wolnorynkowego, dokonywanej przez państwa posocjalistyczne. Wskaźnik restrukturyzacji przedsiębiorstw bada zmiany, które zachodziły w tych państwach w ramach szeroko pojętego funkcjonowania przedsiębiorstw i zawiera w sobie takie informacje, jak: udział procentowy sektora prywatnego w tworzeniu produktu krajowego brutto (PKB), odsetek zatrudnionych $\mathrm{w}$ sektorze prywatnym, dotacje budżetowe (w \% PKB), odsetek pracujących 
w przemyśle, zmiana wydajności pracy w przemyśle (w \%), stopa inwestycji. Wskaźnik ten przyjmuje wartości od 1 do $4+\mathrm{i}$ oceny te odpowiadają następującym zmianom:

1 - miękkie ograniczenia budżetowe przedsiębiorstw, niewielki zakres reform w kierunku promowania porządku korporacyjnego (ang. corporate governance),

2 - stopniowa redukcja polityki dotowania przedsiębiorstw, powolne zmiany przepisów upadłościowych, znikome działania na rzecz wzmacniania konkurencji i poprawy systemu zarządzania oraz nadzoru przedsiębiorstw,

3 - konsekwentne działania w kierunku wzmocnienia ograniczeń budżetowych firm i promowania efektywnego ładu korporacyjnego (np. prywatyzacja wraz z redukcją dotacji i/lub wdrożenie przepisów upadłościowych),

4 - znacząca poprawa systemu zarządzania i nadzoru przedsiębiorstw, wzrost inwestycji na poziomie przedsiębiorstw,

4+ - charakterystyka sektora przedsiębiorstw zgodna z normami rozwiniętych gospodarek, efektywny system zarządzania i nadzoru przedsiębiorstw wspomagany poprawnym funkcjonowaniem rynku finansowego (Bąk 2006).

Na podstawie zaczerpniętych z Transition Reports (z lat 1999-2009) danych statystycznych dotyczących wskaźnika restrukturyzacji przedsiębiorstw przeanalizowano sytuację w 25 państwach leżących w Europie Środkowo-Wschodniej i Azji Centralnej, czyli prawie wszystkich państwach, które po 1991 roku (po rozpadzie Związku Socjalistycznych Republik Radzieckich - ZSRR) rozpoczęły reformy zmierzające do utworzenie nowego ładu społeczno-gospodarczego. Z państw europejskich z analizy wyłączono jedynie Bośnię i Hercegowinę oraz Serbię i Czarnogórę ze względu na brak dostępnych kompletnych danych statystycznych w omawianym zakresie. Dane dla wszystkich państw w analizowanych latach przedstawia tabela 1. Dla lepszej czytelności wartość wskaźnika zamieniono na barwę. W ten sposób łatwiej można odczytać, jak powstawały grupy państw o różnych wartościach wskaźnika reform i które państwa należały do jakich grup na przestrzeni badanych lat (tab. 2).

$\mathrm{Z}$ danych zawartych $\mathrm{w}$ tabeli 2 wynika, że warunki początkowe dla reform w sektorze przedsiębiorstw we wszystkich analizowanych państwach były niemal takie same. Na 25 państw w 1991 roku tylko trzy miały wskaźnik restrukturyzacji na poziomie 2 (Czechosłowacja, Polska, Węgry), czyli świadczący o stopniowej redukcji dotowania przedsiębiorstw i wprowadzaniu, ale na niewielka skalę, przepisów upadłościowych i wzmacniających konkurencję. Reszta państw natomiast startowała z poziomu niżej, czyli ze wskaźnikiem równym 1, a zatem nie zaobserwowano istotnych reform w zakresie przedsiębiorstw, jedynie można mówić o niewielkich ograniczeniach budżetowych przedsiębiorstw (ryc. 1).

Ryc. 1. Grupy państw wg wartości wskaźnika restrukturyzacji w 1991 roku

\begin{tabular}{|l|}
\hline 1,00 \\
\hline 1,70 \\
\hline 2,00 \\
\hline 2,30 \\
\hline 2,70 \\
\hline 3,00 \\
\hline 3,30 \\
\hline 3,70 \\
\hline
\end{tabular}

\begin{tabular}{|c|c|c|c|}
\hline ALB & GEO & RUS & CZE-SVK \\
\hline ARM & KAZ & ROM & POL \\
\hline AZE & KGZ & SVN & HUN \\
\hline BLR & LTU & TJK & \\
\hline BGR & LVA & TKM & \\
\hline HRV & MKD & UKR & \\
\hline EST & MDA & UZB & \\
\hline
\end{tabular}

Źródło: opracowanie własne na podstawie EBRD, Transition Report 2000. 


\begin{tabular}{|c|c|c|c|c|c|c|c|c|c|c|c|c|c|c|c|c|c|c|c|c|c|c|c|c|c|c|}
\hline ڤ్సે & $\hat{\imath}$ & $\stackrel{m}{\mathrm{i}}$ & $\sim$ & $\approx$ & $\vec{i}$ & $m$ & نَ & $\hat{m}$ & $\hat{i}$ & $\mathrm{~N}$ & 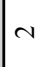 & $m$ & $m$ & $\hat{i}$ & $\sim$ & $\ddot{m}$ & $\hat{\mathrm{i}}$ & $\hat{i}$ & $\hat{m}$ & $m$ & $\sim$ & - & $\begin{array}{c}2 \\
i\end{array}$ & $\approx$ & $\hat{m}$ & 8 \\
\hline$\stackrel{\infty}{\text { సે }}$ & $\hat{i}$ & $\hat{i}$ & $\sim$ & $\approx$ & $\hat{i}$ & $m$ & فُ & $\hat{m}$ & $\hat{i}$ & $N$ & $N$ & $m$ & $m$ & $\hat{i}$ & $\sim$ & $\vec{m}$ & $\hat{i}$ & $\hat{i}$ & $\hat{m}$ & $m$ & $\approx$ & - & $\sim$ & $\approx$ & $\hat{m}$ & \\
\hline 今్ & $\begin{array}{c}m \\
i\end{array}$ & $\hat{r}$ & $\sim$ & - & $\vec{i}$ & $m$ & $\stackrel{m}{m}$ & $\hat{m}$ & $\hat{\sim}$ & $N$ & $N$ & $m$ & $m$ & $\hat{i}$ & $N$ & $\vec{m}$ & $\hat{i}$ & $\vec{i}$ & $\hat{m}$ & $m$ & $\approx$ & - & $\sim$ & $\approx$ & $\hat{n}$ & \\
\hline ڤ્ڤે & $\begin{array}{c}m \\
i\end{array}$ & $\stackrel{m}{i}$ & $\sim$ & - & $\hat{i}$ & $m$ & $\stackrel{m}{m}$ & $\hat{m}$ & $\stackrel{m}{i}$ & $N$ & N & $m$ & $m$ & $\hat{\tilde{i}}$ & $N$ & $\hat{m}$ & $\stackrel{m}{i}$ & $\vec{i}$ & $\hat{m}$ & $m$ & $\approx$ & -1 & $\sim$ & $\approx$ & $\hat{n}$ & \\
\hline 气ે & $\sim$ & $\hat{i}$ & $\sim$ & - & $\hat{i}$ & $m$ & $\stackrel{m}{m}$ & $\hat{m}$ & $\hat{i}$ & $N$ & $N$ & $m$ & $m$ & $\hat{i}$ & $\sim$ & $\dot{m}$ & $\hat{i}$ & $\hat{i}$ & $\hat{m}$ & $m$ & $\approx$ & - & $\sim$ & $\approx$ & $\hat{m}$ & \\
\hline ఫે్ & $\sim$ & $\hat{r}$ & $\sim$ & - & $\hat{i}$ & $m$ & $\stackrel{m}{m}$ & $\begin{array}{l}m \\
m\end{array}$ & $\sim$ & $N$ & $N$ & $m$ & $m$ & $\hat{n}$ & $\approx$ & $m^{m}$ & $\stackrel{m}{i}$ & $\sim$ & $\stackrel{m}{m}$ & $m$ & $\approx$ & - & $\sim$ & $\approx$ & $\stackrel{m}{m}$ & \\
\hline 气ิે & $\sim$ & $\stackrel{m}{i}$ & $\sim$ & - & $\hat{i}$ & is & $\stackrel{m}{m}$ & $\begin{array}{c}m \\
m\end{array}$ & $\sim$ & 4 & $N$ & $m$ & $m$ & $\stackrel{m}{i}$ & $\approx$ & $\stackrel{m}{m}$ & $\stackrel{m}{\mathrm{i}}$ & $\sim$ & $\stackrel{m}{m}$ & $m$ & $\approx$ & - & $\sim$ & $\approx$ & $\stackrel{m}{m}$ & \\
\hline 气ิ & $\sim$ & $\stackrel{m}{i}$ & $\sim$ & - & $\stackrel{m}{i}$ & $\hat{i}$ & $\stackrel{m}{m}$ & $\begin{array}{c}m \\
m\end{array}$ & $\sim$ & $N$ & 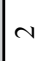 & $m$ & $\vec{i}$ & $\hat{n}$ & $\sim$ & $\stackrel{m}{m}$ & $\stackrel{m}{i}$ & $N$ & $m$ & $m$ & $\approx$ & -1 & $N$ & $\approx$ & $\stackrel{m}{m}$ & \\
\hline ड్̀̄ & $\sim \mid$ & $\sim$ & $\sim \mid$ & - & $\stackrel{m}{i}$ & $\hat{i}$ & $\stackrel{m}{m}$ & $\begin{array}{c}m \\
m\end{array}$ & $\sim$ & $N$ & $\sim$ & $\hat{i}$ & $\vec{i}$ & $\hat{i}$ & $\sim$ & $\stackrel{m}{m}$ & $\stackrel{m}{i}$ & $N$ & $n$ & $\hat{i}$ & $\approx$ & - & $\sim$ & $\approx$ & $m$ & \\
\hline ఫ్సి & $\sim$ & $\sim$ & $\sim$ & - & $\underset{i}{n}$ & $\vec{i}$ & $\stackrel{m}{m}$ & $m$ & 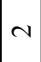 & $N$ & $N$ & $\hat{i}$ & $\vec{i}$ & $\hat{i}$ & $N$ & $m$ & $N$ & $\sim$ & $m$ & $\hat{i}$ & $\approx$ & - & $\sim$ & $\approx$ & $m$ & \\
\hline ڤे & $\sim \mid$ & $N$ & $\approx$ & - & $\stackrel{m}{i}$ & $\hat{i}$ & $m$ & $m$ & $\sim$ & $N$ & 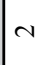 & $\hat{i}$ & $\hat{i}$ & $N$ & $\sim$ & $m$ & $\Rightarrow$ & $\sim$ & $m$ & तi & $\approx$ & $\approx$ & $\sim$ & $\sim$ & $\stackrel{m}{m}$ & \\
\hline$\stackrel{\infty}{\varrho}$ & $\sim \mid$ & $\sim$ & $\approx$ & - & $\hat{i}$ & $\vec{i}$ & $m$ & $m$ & $\sim$ & $N$ & $N$ & $\hat{i}$ & $\vec{i}$ & $N$ & $N$ & $m$ & $\sim$ & $\sim$ & $\hat{i}$ & $\hat{i}$ & $\approx$ & $\approx$ & $\sim$ & $\sim$ & $m^{m}$ & \\
\hline$\hat{\sigma}$ & $\sim$ & $\sim$ & $\approx$ & - & $\begin{array}{l}n \\
i\end{array}$ & $\vec{i}$ & $m$ & $m$ & $\sim$ & $N$ & $N$ & $\hat{\bar{i}}$ & $\vec{i}$ & $N$ & $N$ & $m$ & $\sim$ & $N$ & $\hat{i}$ & $\hat{i}$ & -1 & $\approx$ & $\sim$ & $N$ & $n$ & \\
\hline ڤั & $\sim$ & $\sim$ & $\approx$ & $\approx$ & $\sim$ & $\hat{i}$ & $m$ & $m$ & $\sim$ & $N$ & $N$ & $m$ & $m$ & $N$ & $N$ & $m$ & $\sim$ & $\sim$ & $m$ & $\overrightarrow{\mathrm{i}}$ & -1 & - & $N$ & $N$ & $m$ & \\
\hline 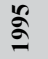 & $\sim$ & $\sim$ & $\approx$ & $\approx$ & $\sim$ & $\sim$ & $m$ & $m$ & $\sim$ & - & $N$ & $N$ & $N$ & $N$ & $\sim$ & $m$ & $\sim$ & $N$ & $m$ & $\hat{\mathrm{i}}$ & -1 & - & $\sim$ & $N$ & $m$ & \\
\hline 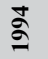 & $\sim$ & - & - & $\sim$ & $\sim$ & $\sim$ & $m$ & $m$ & - & - & $N$ & $\sim$ & $N$ & $N$ & $\sim$ & $m$ & $\sim$ & $\sim$ & $m$ & $m$ & -1 & - & -1 & - & $m$ & \\
\hline$\stackrel{\Omega}{\sigma}$ & -1 & - & - & - & - & -1 & $m$ & $m$ & - & - & - & $N$ & $N$ & - & - & $m$ & -1 & $\sim$ & $m$ & $N$ & -1 & - & -1 & - & $m$ & \\
\hline$\tilde{\sigma}$ & -1 & - & -1 & - & - & -1 & $\sim$ & $N$ & - & - & - & - & $N$ & - & - & $\sim$ & -1 & -1 & $\sim$ & - & -1 & - & -1 & - & $m$ & \\
\hline $\bar{\sigma}$ & - & - & - & - & - & - & $\sim$ & - & - & - & - & - & - & - & - & $N$ & - & - & $\sim$ & - & -1 & - & -1 & - & $\sim$ & \\
\hline 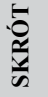 & $\begin{array}{l}\stackrel{n}{\ell} \\
\end{array}$ & $\sum_{\frac{\pi}{\alpha}}$ & 通 & 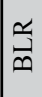 & $\mid \begin{array}{r}\text { 足 } \\
\text { | }\end{array}$ & $\gtrsim$ & 눠 & \begin{tabular}{l}
$\vec{t}$ \\
\multicolumn{1}{|c}{}
\end{tabular} & 号 & $\underset{\Xi}{\searrow}$ & $\begin{array}{l}N \\
\mathcal{U} \\
x\end{array}$ & ? & 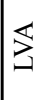 & $\stackrel{\theta}{\Sigma}$ & $\stackrel{\Xi}{\stackrel{\Sigma}{\Sigma}}$ & 웅 & $\stackrel{\infty}{\curvearrowright}$ & $\left|\begin{array}{l}\Sigma \\
0 \\
\simeq\end{array}\right|$ & $\sum_{i s}^{1}$ & $\underset{n}{Z}$ & 曾 & $\underset{Z}{\Sigma}$ & $\mid \frac{a}{2}$ & $\stackrel{0}{\mathcal{N}}$ & 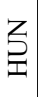 & \\
\hline 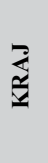 & 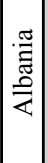 & 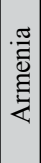 & 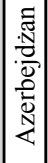 & $\frac{0}{0}$ & 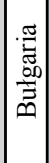 & 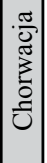 & 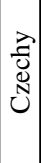 & 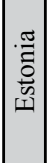 & 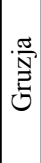 & 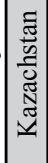 & 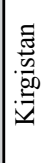 & 莡 & لَّ & 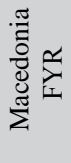 & 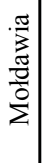 & $\begin{array}{l}\frac{\pi}{\tilde{U}} \\
\frac{\pi}{0} \\
\stackrel{0}{0}\end{array}$ & $\mid \begin{array}{l}\cdot \frac{\pi}{2} \\
\stackrel{2}{\simeq} \\
\approx\end{array}$ & 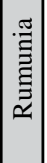 & $\begin{array}{l}\frac{\pi}{3} \\
\frac{\pi}{3} \\
0 \\
\dot{\sigma}\end{array}$ & $\begin{array}{l}. \frac{\pi}{\pi} \\
0 \\
\frac{0}{0} \\
\frac{0}{n}\end{array}$ & 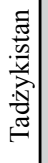 & 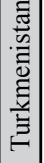 & 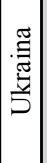 & 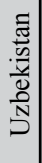 & $\begin{array}{l}\overrightarrow{2} \\
\overrightarrow{5} \\
3\end{array}$ & 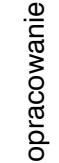 \\
\hline$\dot{\AA}$ & -1 & $N$ & $m$ & $\nabla$ & $n$ & $0 \mid$ & - & $\infty$ & $a$ & 으 & $=$ & $\simeq$ & $\cong$ & $\Xi$ & $\because$ & $\stackrel{0}{-}$ & $\Xi$ & $\infty$ & 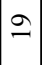 & तి & $\vec{\sim}$ & $\tilde{N}$ & $\tilde{\sim}$ & $\underset{\sim}{\sim}$ & $\approx$ & \\
\hline
\end{tabular}




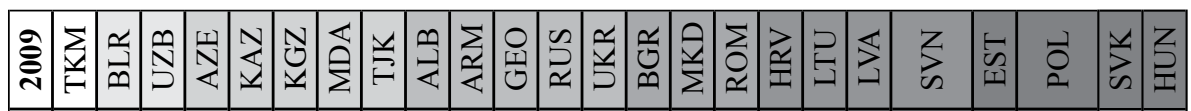

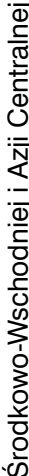

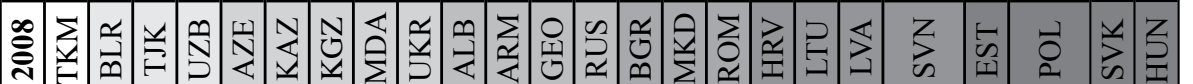

के

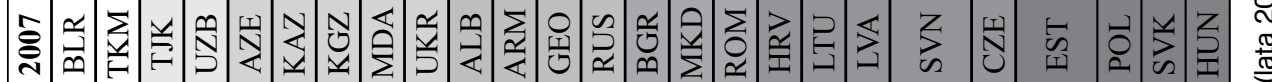

N

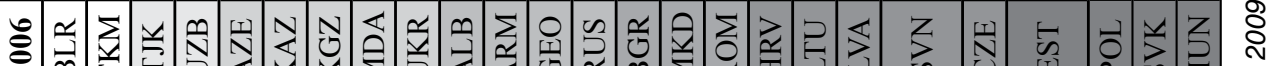

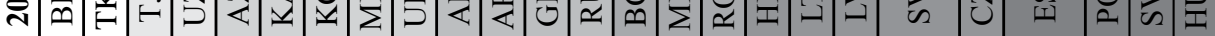

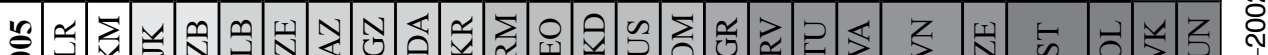

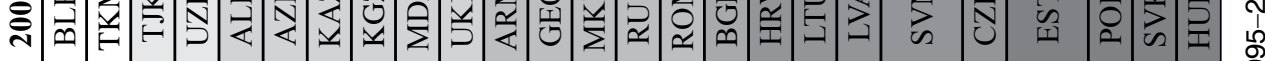

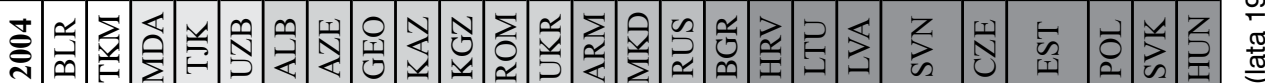

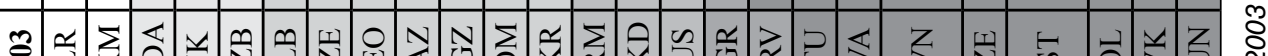

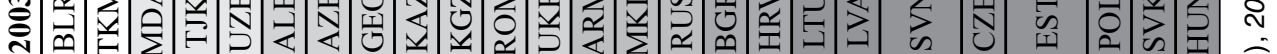

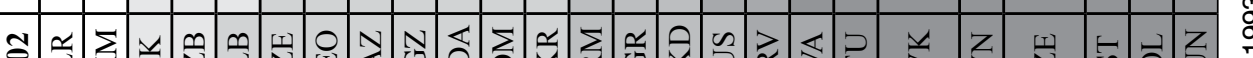

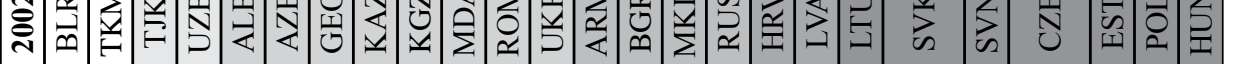

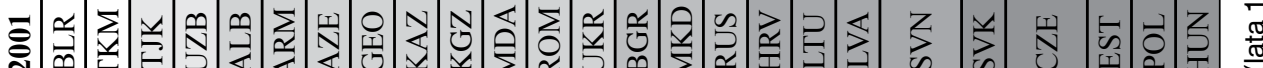

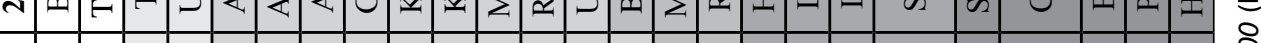

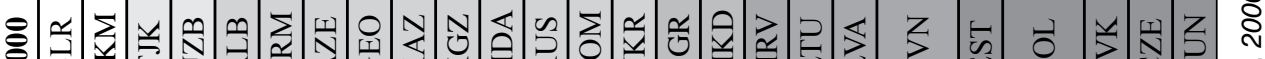

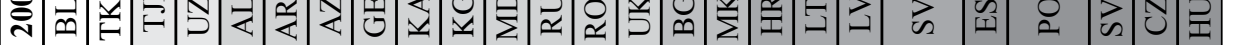

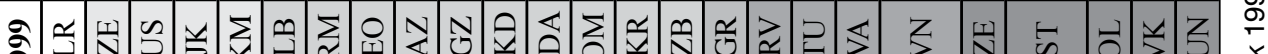

まे

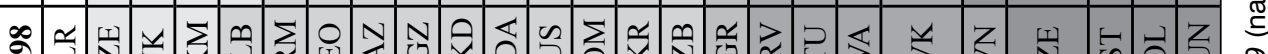

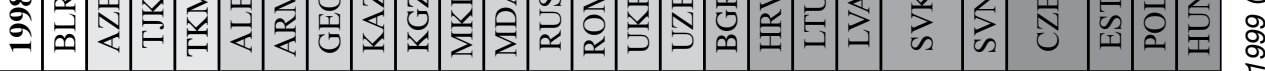

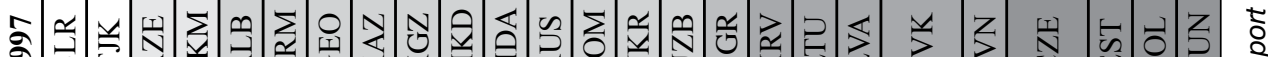

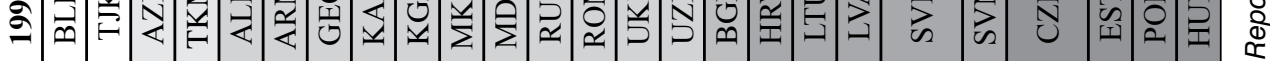

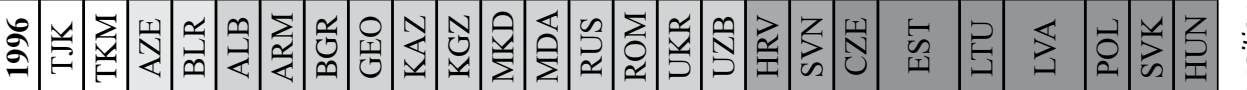

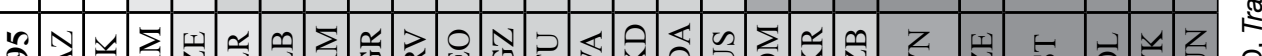

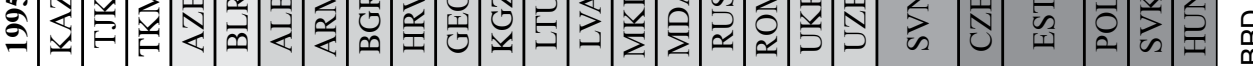

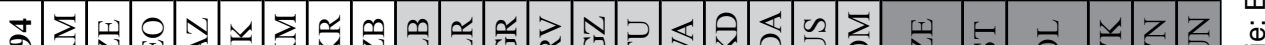

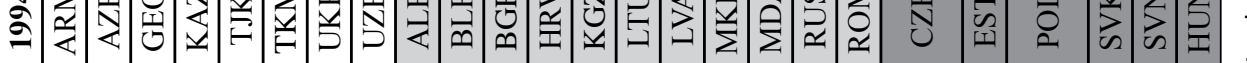

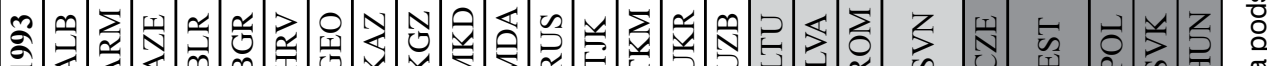

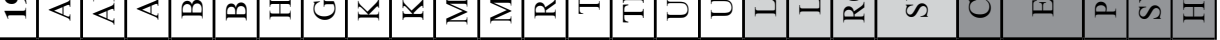

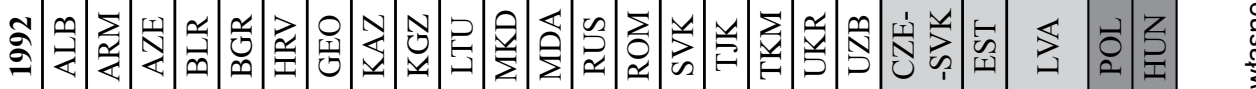

3

เั

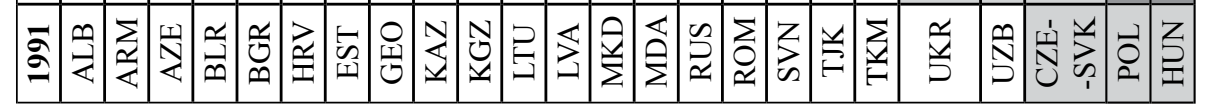

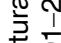

旁官

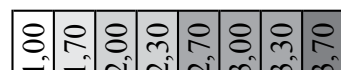

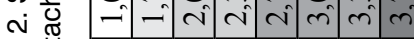

$\dot{0} \frac{\pi}{3}$

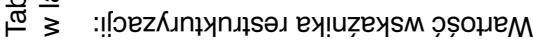


W kolejnych latach (1992-1993) zanotowano niewielkie zmiany - wciąż najliczniejszą grupę stanowiły państwa o wskaźniku restrukturyzacji na poziomie 1, z tym, że państwa wyróżniające się na początku już w 1993 roku osiągnęły wartość wskaźnika 3 i są to państwa, które przez cały badany okres są liderami w transformacji sektora przedsiębiorstw (i w transformacji ogółem), czyli: Czechy, Polska, Słowacja, Węgry, a także Estonia. Państwa te konsekwentnie wdrażały ograniczenia budżetowe firm oraz promowały kulturę ładu korporacyjnego. Do dość silnych państw należą także Litwa, Łotwa, Rumunia i Słowenia, które dopiero zaczęły wprowadzać istotne ograniczenia dotacji dla przedsiębiorstw. Nie wszystkie z nich utrzymały tę przewagę w latach kolejnych.

W 1994 roku nastąpiła zmiana struktury państw pod względem poziomu wskaźnika restrukturyzacji, ponieważ aż osiem państw zanotowało wzrost jego wartości o 1 pkt. W rezultacie powstała grupa jedenastu państw o wskaźniku na poziomie 2 , którą tworzyły głównie państwa bałkańskie oraz państwa Europy Wschodniej. Na przeciwległych biegunach znalazły się dwie grupy państw: dotychczasowi liderzy (czyli przede wszystkim państwa Europy Środkowej) i państwa słabe (czyli państwa Azji Centralnej i Ukraina).

Grupa państw tzw. średnich, czyli tych, które w połowie lat 90. osiągnęły wartość wskaźnika na poziomie 2 (ryc. 2), utrzymała się w raczej niezmienionym składzie aż do przełomu dekad i dopiero z początkiem XXI wieku rozpadła się na skutek przechodzenia państw do wyższych grup. Warto jednak zaznaczyć, że kraje te na stosunkowo długi czas utknęły na poziomie średnim (w porównaniu z pozostałymi państwami).

Ryc. 2. Grupy państw wg wartości wskaźnika restrukturyzacji w 1996 roku

\begin{tabular}{|c|c|c|c|c|c|c|}
\hline 1,00 & TJK & AZE & ALB & MKD & HRV & $\mathrm{CZE}$ \\
\hline 1,70 & TKM & BLR & ARM & MDA & SVN & EST \\
\hline 2,00 & & & BGR & RUS & & LTU \\
\hline 2,30 & & & GEO & ROM & & LVA \\
\hline 2,70 & & & KAZ & UKR & & POL \\
\hline 3,00 & & & KGZ & UZB & & SVK \\
\hline 3,30 & & & & & & HUN \\
\hline 3,70 & & & & & & \\
\hline
\end{tabular}

Źródło: opracowanie własne na podstawie: EBRD, Transition Report 2003.

Druga połowa lat 90 . to okres intensywnych zmian w dokonywaniu restrukturyzacji przedsiębiorstw, co znalazło swój wyraz w dużym zróżnicowaniu ocen nadanych państwom. Otóż Europejski Bank Odbudowy i Rozwoju w swoich ocenach wprowadził także wartości pośrednie, w wyniku czego w 1998 roku państwa tworzyły już siedem grup wg poziomu analizowanego wskaźnika, wobec pięciu grup z roku 1996 (ryc. 2). Jeśli chodzi o grupę liderów, to tworzą ją Czechy, Polska i Estonia. Słowacja spadła do grupy niższej, a Węgry osiągnęły (jako pierwsze państwo) wskaźnik równy 3,3. Do 2001 roku dość mocną pozycję osiągnęły Chorwacja, Słowenia, Litwa i Łotwa, a także nieco silniejsza Słowacja (odpowiednio oceny 2,7 i 3,0). Trochę słabsze, ale wciąż ze wskaźnikiem reform powyżej 2, były Bułgaria, Macedonia oraz Rosja $(2,3)$, które to kraje awansowały z grupy średnich państw. Wskutek tego grupa ta zaczęła się 
zmniejszać, co jest zauważalne w dalszych latach. Natomiast dwie najsłabsze grupy (odpowiednio wartość 1,7 i 1) tworzyły Tadżykistan z Uzbekistanem oraz Białoruś z Turkmenistanem (ryc. 3).

Ryc. 3. Grupy państw wg wartości wskaźnika restrukturyzacji w 2001 roku

\begin{tabular}{|l|}
\hline 1,00 \\
\hline 1,70 \\
\hline 2,00 \\
\hline 2,30 \\
\hline 2,70 \\
\hline 3,00 \\
\hline 3,30 \\
\hline 3,70 \\
\hline
\end{tabular}

\begin{tabular}{|c|c|c|c|c|c|c|c|}
\hline BLR & TJK & ALB & KAZ & BGR & HRV & SVK & $\overline{\mathrm{CZE}}$ \\
\hline TKM & UZB & ARM & KGZ & MKD & LTU & & EST \\
\hline & & AZE & MDA & RUS & LVA & & POL \\
\hline & & GEO & $\mathrm{ROM}$ & & SVN & & $\overline{\mathrm{HUN}}$ \\
\hline & & & UKR & & & & \\
\hline
\end{tabular}

Źródło: opracowanie własne na podstawie: EBRD, Transition Report 2003.

W kolejnych latach wciąż utrzymuje się duża liczba grup państw (8), jednak zmienia się ich struktura. Otóż, jak już zaznaczano wcześniej, przede wszystkim coraz mniej państw należy do grupy średniej (wskaźnik równy 2), z racji coraz lepszych ocen (na poziomie 2,3) przydzielanych takim państwom, jak: Armenia, Gruzja, Rumunia, Albania (do roku 2006) czy wreszcie Ukraina (2009 rok). Właśnie tych grup dotyczą największe zmiany w pierwszej dekadzie XXI wieku, ponieważ grupa najsilniejszych, jak i najsłabszych państw utrzymywała się w zasadzie bez zmian. Warto zaznaczyć, że już w 2005 roku liderzy (Estonia, Polska, Słowacja, Węgry) uzyskali notę 3,7 i pozostali na tym poziomie do końca badanego okresu. Ocena ta oznacza zaawansowane reformy w sektorze przedsiębiorstw, takie jak poprawa systemu zarządzania i nadzoru firm oraz wzrost inwestycji. Należy zauważyć, że w ocenach nieco niżej $(3,3)$ lokowały się Czechy. Natomiast najsłabszymi krajami pozostały: Uzbekistan, Tadżykistan oraz Białoruś i Turkmenistan (ryc. 4). Z państw, które polepszyły swoje oceny w badanym zakresie po roku 2000, wymienić należy także Litwę, Łotwę, Słowenię, Chorwację, ponieważ jest to grupa doganiająca liderów - wartość wskaźnika reform na poziomie około 3,0.

Ryc. 4. Grupy państw wg wartości wskaźnika restrukturyzacji w 2006 roku

\begin{tabular}{|l|}
\hline 1,00 \\
\hline 1,70 \\
\hline 2,00 \\
\hline 2,30 \\
\hline 2,70 \\
\hline 3,00 \\
\hline 3,30 \\
\hline 3,70 \\
\hline
\end{tabular}

\begin{tabular}{|c|c|c|c|c|c|c|c|}
\hline BLR & TJK & AZE & ALB & BGR & HRV & $\mathrm{CZE}$ & EST \\
\hline TKM & UZB & KAZ & ARM & MKD & LTU & & POL \\
\hline & & KGZ & GEO & ROM & LVA & & SVK \\
\hline & & MDA & RUS & & SVN & & HUN \\
\hline & & UKR & & & & & \\
\hline
\end{tabular}

Źródło: opracowanie własne na podstawie: EBRD, Transition Report 2009. 
W ostatnich latach analizowanego okresu nieco wyższe oceny udało się uzyskać państwom z najsłabszych grup, były to: Ukraina $(2,3)$, Tadżykistan $(2,0)$ i Białoruś $(1,7)$. Za rok 2009 brakuje danych dla Czech, należy się jednak spodziewać, że utrzymały swoją notę albo dołączyły do najsilniejszych państw. Ogólnie jednak sytuacja kształtowała się bardzo podobnie jak w latach poprzednich (ryc. 5). A zatem liderami były Estonia, Polska, Słowacja, Węgry (należy przypuszczać, że Czechy można zaliczyć do tej grupy), dla których wskaźnik wyniósł 3,7 pkt., co oznacza zbliżanie się cech sektora przedsiębiorstw tych państw do norm gospodarek wysoko rozwiniętych. Następnie silną pozycję (3 pkt.) miały: Chorwacja, Litwa, Łotwa oraz Słowenia (mocne ograniczenia budżetowe firm, wprowadzania ładu korporacyjnego). Do państw o średniej pozycji (wskaźnik w przedziale 2-3 pkt.) zaliczyć można: Albanię, Armenię, Bułgarię, Gruzję, Macedonię, Rosję, Rumunię, Ukrainę (z czego najsłabsze i najpóźniej dołączone są: Albania, Gruzja, Ukraina, a stosunkowo najsilniejsze w tej grupie - Bułgaria, Macedonia, Rumunia). W tych krajach osiągnięto różny poziom ograniczenia dotacji przedsiębiorstw, powoli wprowadzane są działania wzmacniające konkurencję i poprawiające system zarządzania przedsiębiorstw. Grupę słabych w tym układzie państw tworzą: Azerbejdżan, Kazachstan, Kirgistan, Mołdawia, Tadżykistan. Mniej więcej od połowy lat 90. obserwuje się w nich brak zmian - wskaźnik utrzymuje się na poziomie 2 pkt. i nie przekracza go, co oznacza, że kraje te w swych reformach były na etapie powolnej redukcji dotacji dla przedsiębiorstw, w zasadzie nie wspomagało się w nich wolnej konkurencji na rynku.

Zdecydowanie najsłabszymi państwami były: Białoruś, Uzbekistan (po 1,7) i Turkmenistan (1). Każde z tych państw było w grupie wyżej i spadło, co może świadczyć o tym, że wprowadzone działania nie przyniosły oczekiwanych rezultatów. Państwa te nie uzyskały w ciągu 19 badanych lat noty wyższej niż 2,0 (przy czym najgorszą sytuację odnotowano w Turkmenistanie, w którym w roku końcowym wskaźnik restrukturyzacji był równy 1).

Ryc. 5. Grupy państw wg wartości wskaźnika restrukturyzacji w 2009 roku

\begin{tabular}{|l|}
\hline 1,00 \\
\hline 1,70 \\
\hline 2,00 \\
\hline 2,30 \\
\hline 2,70 \\
\hline 3,00 \\
\hline 3,30 \\
\hline 3,70 \\
\hline
\end{tabular}

\begin{tabular}{|c|c|c|c|c|c|c|}
\hline TKM & BLR & AZE & ALB & BGR & HRV & $\overline{E S T}$ \\
\hline & UZB & KAZ & $\overline{\text { ARM }}$ & MKD & LTU & POL \\
\hline & & KGZ & GEO & ROM & LVA & SVK \\
\hline & & MDA & RUS & & SVN & HUN \\
\hline & & TJK & UKR & & & \\
\hline
\end{tabular}

Źródło: opracowanie własne na podstawie: EBRD, Transition Report 2009.

Jak można zauważyć, ogólnie z dwóch mało zróżnicowanychi grup (1990 rok) otrzymujemy pięć grup państw (2009 rok) o zróżnicowanej liczebności i wielkości wskaźnika.

Jeśli chodzi o zróżnicowanie przestrzenne wskaźnika restrukturyzacji przedsiębiorstw, to zauważalne jest, że najsilniejsze kraje leżą w części Europy Środkow-Wschodniej, graniczącej z Zachodem Najsłabsze natomiast okazują się państwa Azji Centralnej (tzw. republiki poradzieckie) oraz wschodnie państwa Europy Środkowo-Wschodniej (Ukraina, Białoruś), czyli państwa mocno powiązane wcześniej z ZSRR. 
Analiza wskaźnika restrukturyzacji w latach 1991-2009 dla 25 państw posocjalistycznych wykazała znaczne zróżnicowanie w zakresie i tempie przechodzenia od gospodarki centralnie planowanej do gospodarki wolnorynkowej poszczególnych krajów w obrębie reform sektora przedsiębiorstw. Reformy te obejmowały różnego rodzaju działalności, między innymi: ograniczanie lub likwidowanie dotacji budżetowych dla nierentownych przedsiębiorstw, prywatyzację państwowych firm, działania na rzecz wzmocnienia konkurencji na rynku, wdrażanie przepisów upadłościowych, poprawę zarządzania i nadzoru przedsiębiorstw, czyli, ogólnie mówiąc, budowę ładu korporacyjnego.

Nie wszystkie państwa osiągnęły w tej kwestii dobre rezultaty, lecz trzeba zaznaczyć, że nie zawsze wynikało to z nieudolności władz czy innych subiektywnych przyczyn. W interpretacji porównań tak zróżnicowanej zbiorowości, jak państwa powstałe (lub uzyskujące pełną niezależność polityczną i gospodarczą) po rozpadzie Związku Radzieckiego, należy uwzględniać specyfikę regionu, tak pod względem kulturowym i społecznym, jak też politycznym czy gospodarczym.

Z jednej strony mamy do czynienia z państwami Europy Środkowej, takimi jak Polska, Czechy, które zawsze mocniej były związane z kulturą Zachodu niż państwa Azji Centralnej, które nie mają praktycznie żadnych tradycji wyrosłych na gruncie myśli kultury Zachodu. Państwa Europejskie w mniejszym lub większym stopniu starały się „dogonić” Państwa Europy Zachodniej w rozwoju gospodarczym i wyznaczając sobie taki cel, upodobniały się w sferze społecznej, politycznej czy ekonomicznej do zachodnich społeczeństw. Tymczasem w państwach Azji Centralnej takich dążeń nie było i nie ma - w zasadzie nigdy nie funkcjonowały tu demokratyczne sposoby przekazywania władzy (Gierańczyk 2009). Warto w tym miejscu zacytować prezydenta Uzbekistanu K. Isloma, który stwierdził, że: „demokracja, która nie znalazła miejsca w kulturze narodu, nie może stać się składnikiem stylu jego życia” (Roszyk 2001).

W wypadku Azji Centralnej, czyli takich państw, jak Kazachstan, Kirgistan, Turkmenistan, Tadżykistan czy Uzbekistan, społeczeństwo nigdy nie miało zamiaru dążyć do zachodniego modelu opartego na kapitalizmie. Różnica ta wyraża się nawet w terminologii stosowanej w odniesieniu do zmiany systemu polityczno-gospodarczego po 1991 roku. Otóż w państwach Europy Środkowo-Wschodniej dość zgodnie używa się terminu transformacja (ang. transformation, transition), natomiast w Azji Centralnej dominuje termin modernizacja, który podkreślać ma, że państwa te poszukują dla siebie innego zarówno modelu przejścia od gospodarki centralnie planowanej, jak i samego celu tegoż przejścia. Nie przyjmują zatem zachodnioeuropejskiego wzorca dążenia do kapitalistycznego systemu gospodarczego, zastępując go własną wizją ,gospodarki wolnorynkowej o charakterze socjalnym” (Gortat 2000). A zatem myśl przewodnia reform gospodarczych zbliżona jest do tej wprowadzanej w Chinach po 1978 roku. Ponownie posługując się słowami prezydenta, tym razem Turkmenistanu, S. Nijazowa, można przedstawić ogólną wizję celu przemian systemowych po 1991 roku, którą było: „stworzenie rozwiniętej i społecznie zorientowanej gospodarki rynkowej typu mieszanego, przy jednoczesnym udziale państwowych mechanizmów makroekonomicznych" (Kuźmina 2005).

Choć prezydent Nijazow wypowiadał się tylko na temat przemian w swoim kraju, z powodzeniem można przyjąć, że był to wspólny czynnik ideowy dla państw całego regionu. Stąd też porównywanie skuteczności reform wprowadzanych w państwach Europy Środkowo-Wschodniej i Azji Centralnej, które zresztą odbywa się według wzorców zachodnioeuropejskich (Europejski Bank Odbudowy i Rozwoju), musi uwzględniać różnice w mentalności i tradycjach porównywanych społeczeństw, z których wynikały cele przeprowadzanych reform. 
Niemniej jednak same wnioski dotyczące stanu sektora przedsiębiorstw, choć należy je wyciągać ostrożnie, są prawidłowe. Państwa Europy Środkowo-Wschodniej, będące pod dużym wpływem wzorców zachodnioeuropejskich, w swoich reformach, wprowadzały działania mające na celu upodobnienie norm swojego sektora przedsiębiorstw do norm panujących w gospodarkach wysoko rozwiniętych. Spośród nich najlepiej radziły sobie te, które znajdowały się w bliskim sąsiedztwie państw Europy Zachodniej (m.in.: Czechy, Słowacja, Polska, Węgry). Gorzej radziły sobie państwa leżące na wschodzie i na południu omawianego regionu. Spośród państw Azji Centralnej nieco bliższe zachodnioeuropejskiemu pojmowaniu reform gospodarczych w zakresie sektora przedsiębiorstw były Kazachstan i Kirgistan, natomiast w pozostałych państwach działania gospodarcze w tej kwestii nie spełniały warunków europejskiego rozumienia restrukturyzacji przedsiębiorstw.

\section{Literatura}

1. Balcerowicz L., Gelb A., 1995, Makropolityka w przechodzeniu do gospodarki wolnorynkowej, Centrum Analiz Społeczno-Ekonomicznych Fundacja Naukowa, Warszawa.

2. Bazydło A., Smętkowski M., Wieloński A., 2001, Inwestycje w specjalnych strefach ekonomicznych a przeksztatcenia strukturalne w przemyśle Polski [w:] Problemy przemian struktur przemysłowych w procesie wdrażania reguł gospodarki rynkowej, Zioło Z. (red.), „Prace Komisji Geografii Przemysłu Polskiego Towarzystwa Geograficznego", nr 3, Warszawa - Kraków - Rzeszów, s. 135-148.

3. Bąk M., 2006, Europa Środkowa i Wschodnia wobec wyzwania transformacyjnego, Wydawnictwo Uniwersytetu Gdańskiego, Gdańsk.

4. European Bank for Reconstruction and Development, Transition Report 1999, 2000, 2003, 2009, http:/www.ebrd.com/pages/research/publications/flagships/transition/archive.shtml

5. Gierańczyk W., 2009, Rozwój społeczeństwa informacyjnego a przedsiębiorczość w krajach transformujących się [w:] Rola przedsiębiorczości w kształtowaniu społeczeństwa informacyjnego, Z. Zioło, T. Rachwał (red.), „Przedsiębiorczość - Edukacja”, nr 5, wydawnictwo Nowa Era, Zakład Przedsiębiorczości i Gospodarki Przestrzennej Instytutu Geografii Uniwersytetu Pedagogicznego im. Komisji Edukacji Narodowej w Krakowie, Warszawa - Kraków, s. 19-36.

6. Gortat R., 2000, Kazachstańska ideologia modernizacji [w:] Kazachstan. Historia - Spoleczeństwo - Polityka, T. Bodio, K.A. Wojtaszczyk (red.), „Współczesna Azja Centralna”, Dom Wydawniczy Elipsa, Warszawa, s. 101-126.

7. Kamińska W., 2006, Wpływ procesów transformacji na rozwój małych firm prywatnych w Polsce [w:] Rola przedsiębiorczości w podnoszeniu konkurencyjności społeczeństwa i gospodarki, Z. Zioło, T. Rachwał (red.), „Przedsiębiorczość - Edukacja”, nr 2, wydawnictwo Nowa Era, Zakład Przedsiębiorczości i Gospodarki Przestrzennej Instytutu Geografii Akademii Pedagogicznej im. Komisji Edukacji Narodowej w Krakowie, Warszawa - Kraków, s. 55-64.

8. Koźmiński A.K., 1998, Odrabianie zaległości. Zmiany w organizacji i zarządzania w byłym bloku socjalistycznym, Wydawnictwo Naukowe PWN, Warszawa.

9. Krajewski S., 2004, Procesy restrukturyzacji dużych przedsiębiorstw. Raport z badań zamawianych przez Ministerstwo Skarbu Państwa, Łódź, www.msp.gov.pl/dokumenty/zalaczniki/2-59.pdf.

10. Kuźmina E.M., 2005, Reformy gospodarcze [w:] Turkmenistan. Historia-Społeczeństwo-Polityka, T. Bodio (red.), „Współczesna Azja Centralna”, Dom Wydawniczy Elipsa, Warszawa, s. 562-576.

11. Misztal S., 2000, Regionalne efekty procesu prywatyzacji przemystu w Polsce w latach 1989-1995 [w:] Problemy transformacji struktur przemystowych $w$ procesie przechodzenia do gospodarki rynkowej, Z. Zioło (red.), „Prace Komisji Przemysłu Polskiego Towarzystwa Geograficznego”, nr 1, Warszawa - Kraków, s. 23-33.

12. Roszyk L., 2001, Transformacja uzbecka: przełom czy kontynuacja? [w:] Uzbekistan. Historia Społeczeństwo - Polityka, T. Bodio (red.), „Współczesna Azja Centralna”, Dom Wydawniczy Elipsa, Warszawa, s. 171-188. 


\section{Restructuring of enterprises in Central-Eastern Europe and Central Asia in the era of transformation}

In 1991 a process of post-socialist transformation has begun together with the collapse of the Union of Soviet Socialist Republics (USSR) in the Central and Eastern Europe (CEE) and Central Asia. This process was chiefly about a transition from centrally planned economy to a free market. Individual countries were introducing economic reforms to a different degree and scope - some countries tried to catch up highly developed countries of the West (mainly the Central European states) more quickly, the others have chosen the path of slow modernization different from the western model of capitalism (the Central Asian states).

This article aims to analyse the processes that take place in the corporate sector during the political changes in countries undergoing transitions from centrally planned economy to market economy. The analysis will employ an enterprise reform index (developed by the European Bank for Reconstruction and Development) for the years between 1991-2009. These processes include both changes in ownership (privatization), and changes within a company (restructuring including assets, products, employment).

In the analysed countries, restructuring processes were carried out differently - much faster in Central - Eastern Europe countries (Czech Republic, Poland, Slovakia, Estonia, Hungary) than in the countries of Central Asia, where reforms were introduced slowly and on a much smaller scale (such as Turkmenistan, Uzbekistan). 